\title{
Transboundary water interaction I: reconsidering conflict and cooperation
}

\author{
Mark Zeitoun · Naho Mirumachi
}

Accepted: 7 August 2008/Published online: 3 September 2008

(C) Springer Science+Business Media B.V. 2008

\begin{abstract}
Whether the inter-state and sub-national tensions over transboundary waters will lead to greater conflict or increased cooperation remains a hotly debated issue. Most work on the subject situates transboundary water conflict and transboundary water cooperation at opposing ends of a continuum. The examination of either conflict or cooperation, we argue, refutes the reality of the vast majority of contexts where cooperation and conflict actually co-exist, and perpetuates the paradigm that any conflict is 'bad', and that all forms of cooperation are 'good'. The efforts of the international water academic and practitioner communities may be better served through a combined reading of conflict and cooperation as transboundary water interaction. Mirumachi's Transboundary Waters Interaction NexuS is offered as a robust method demonstrating that simultaneous consideration of conflict and cooperation is both insightful and possible. Transboundary water interaction is shown to be an inherently political process determined by the broader political context. We examine evidence suggesting that uncritical acceptance of traditional forms of 'cooperative' arrangements may in fact sustain the conflict it was intended to transform. Several other less well-known faces of 'cooperation' are discussed in detail, with examples of narrow, token and coercive cooperation derived from inter-state relations on the Jordan, Nile and Ganges rivers. With a view to paving the way for improved transboundary water sharing and governance, subjectively negative, neutral and positive forms of interaction are defined, and linked with a first approximation of their potential driving forces.
\end{abstract}

Keywords Water conflict · Water cooperation - Hegemony · Hydro-hegemony · Power · Hydropolitics · Jordan River · Ganges River · Nile River

M. Zeitoun $(\bowtie)$

Grantham Institute on Climate Change and the Environment, London School of Economics and Political Science, Tower 2, V901, London WC2A 2AE, UK

e-mail: m.zeitoun@1se.ac.uk

N. Mirumachi

Department of Geography, King's College London, London, UK

e-mail: naho.mirumachi@kcl.ac.uk 


\section{Introduction-a shift from conflict to cooperation?}

The 'water war' weathervane continues to spin round. Upon his return from a visit to warravaged western Sudan, the UN Secretary General Ban Ki-Moon, in September 2007, penned his opinion for the Washington Post, stating that 'Darfur is an environmental crisis-a conflict that grew at least in part from desertification, ecological degradation and a scarcity of resources, foremost among the water' (Ki-Moon 2007).

Ki-Moon's foray into the determining influence of the environment on conflict has drawn sharp criticism from those who understand the political, ethnic, historic and religious roots of the tensions between the Fur, Zaghawa and other people of the region (see, e.g. el-Tom 2007; de Waal 2007). Those who oppose the thesis that scarcity of resources causes violent conflict do so both on the grounds that there is little evidence to support the claims and that-more importantly—such claims have the effect of depoliticising the conflict. If Darfur was heavily forested and as awash in water as it is in unexplored oil, after all, would we expect to see peaceful relations between the government in Khartoum and the SPLA? And would the conflict be resolved if the aid agencies drilled deeper boreholes deep into the fractured sandstone under the shale deposits?

The view that water is an increasingly likely source of violent conflict appears to be part of a very broad and pervasive mindset, perpetuated in part by sensationalist media pieces (see, e.g. The Independent 28 Feb 2006) and UN Secretary Generals. ${ }^{1}$ The international water academic and practitioner community has taken a deeper perspective. Assertions of water-related aspects of environmental determinism (e.g. Fearon 1995; Homer-Dixon 1995a, b; Butts 1997) have been generally discredited (e.g. Levy 2001; Hartmann 2002). Water wars themselves are generally viewed as unfounded hyperbole, thanks in large measure to the path-breaking work of Aaron Wolf, which demonstrates that there are many more instances of states cooperating over shared water resources than struggling over them (Wolf 2004, 2007). Indeed, judging by the mood and statements at the numerous international water fora these days, the looming spectre of water wars appears to be gradually being replaced by a feeling that tensions over transboundary waters are subsiding. The 2006 UN World Water Development Report, for example, asserts that

Increasing sensitivity about the need to integrate competitive demands and stakeholders' interests, in addition to the evolving need for political accommodation and the proactive stance in avoiding conflict, have all contributed to a shift from confrontation to cooperation, from monologue to dialogue and from dissent to consensus (UN 2006, p. 388, emphasis added).

While this understanding of progress towards increasing transboundary water cooperation serves to counter the water wars hype, we assert that it runs the risk of swinging the pendulum back too far. All is not quiet on the waterfront. Conflicts of distribution, comanagement, and utilisation persist, of course, along the Nile, Mekong, Tigris, Jordan, Indus, Ganges, Amu Darya and several other transboundary rivers and aquifers. Confident but unexamined assurances of cooperative developments in some basins carry with them the risk of unexpected outcomes and ineffective policy. The assurances reflect the

\footnotetext{
1 Ki-Moon is in fact more nuanced on this subject than his predecessors (e.g. Lewis 2007). Boutros BoutrosGhali is known for his 1991 quote 'the next war will be fought over water, not politics', a position he reaffirmed in 1997 (Middle East Quarterly 1997) and 2005 (Thomson 2005). For his part, Kofi Annan told the Association of American Geographers that 'fierce competition for freshwater may well become a source of conflict and wars in the future' (UN 2001), though he did add subtlety to the message in emphasising water for cooperation during the 2002 World Water Day.
} 
international academic and practitioner communities' crude understanding of the interplay between cooperation and conflict, and its under-appreciation that transboundary water interaction is an inherently political process.

\subsection{Towards transboundary water interaction}

The tensions over transboundary waters are too sophisticated and complex to be adequately captured by pithy expressions such as 'the absence of war does not mean the absence of conflict' (Zeitoun and Warner 2006, p. 437). Water conflict varies significantly in intensity across basins and across time, and ranges in form from stymied fuming to very public displays of hostility, affecting all levels of society, often even in distant non-riparian circles. Perhaps most significantly, various forms of conflict over water occur almost without exception alongside various forms of cooperation.

The idea that elements of cooperation and conflict co-exist is well understood by any who survive a relationship. It has certainly been noted in the literature of political psychology (e.g. Mac Ginty et al. 2007), conflict resolution (e.g. Vasquez et al. 1995), of transboundary environmental negotiations (e.g. Najam 2002), and of management practice challenges (e.g. Moench et al. 2003; Falkenmark et al. 2007; Wolf 2008). Most projects and research directed at improving the management of relations over transboundary waters, including many that the authors have been involved in, insist on the co-existence from the outset. When it comes to the analysis, however, conflict and cooperation are inevitably treated separately. That separation usually means that the less ugly faces of conflict and less pretty faces of cooperation are overlooked, and the political aspects of the interaction are routinely ignored.

A more robust and nuance understanding is required for analysis and policy to reflect the nuance of transboundary waters conflict and cooperation. This paper is the first of two seeking to contribute to that task, delving deeper into the matter and insisting that (a) conflict and cooperation co-exist, and that more insight and understanding will be gained if they are thought of jointly in terms of interaction, and (b) transboundary water interaction is above all a political process subject to the whims of power as are all political processes. We find that the political context is determining to the point that some faces of cooperation may serve to perpetuate the conflict rather than to resolve it. The next paper in the series examines the role that power plays in strategic uses of conflict and cooperation. Transboundary water interaction refers here to relations of co-existing cooperation and conflicts among communities, groups or states over international or sub-national waters, with a focus here on inter-state interaction.

The paper begins with a review of transboundary water conflict literature and the rather relatively under-theorised world of water 'cooperation'. Analysis of the dual nature of transboundary interaction is then shown to be both possible and very insightful, through the work of Kistin, Daoudy and, in particular, Mirumachi's Transboundary Water Interaction NexuS. The paper ends with a foray cataloguing the faces of transboundary water interaction according to subjectively positive, neutral or negative valuations, and linking them with their drivers.

\section{Reconsidering transboundary water conflict and cooperation}

The purpose of this section is to unearth some of the inherent weaknesses with common conceptions of transboundary water conflict and transboundary water cooperation. The 
most widespread analytical tool-the continuum-is shown to be methodologically compromised for fleshing out the nuance of the complexities involved.

The inter-disciplinary work on transboundary hydropolitics is still grappling with identification of its place in academic and policy circles. Lowi (1993) reminds us that politics over water is generally subordinate to the 'higher' political picture. The work of researchers at the Oregon State University on the transboundary freshwater dispute database (TFDD) and basins at risk project (which yielded the water event intensity scale (WEIS) has helped the analysts of global water cooperation and conflict leap forward in bounds. The summary analysis of the TFDD impressively dispels the water wars myth, with more than two thirds of over 1,800 water-related 'events' fall on the 'cooperative' scale of the WEIS. Of the less than one third of events considered conflictual, most are rated only as 'mild' (Wolf et al. 2003).

The researchers at the International Peace Research Institute Oslo (PRIO) are extending their quantitative examination of water cooperation by according dozens of indicators that qualify the signatories of transboundary water treaties. Brochmann and Gleditsch (2006), Hensel and Brochmann (2007) and Brochmann and Hensel (2008), for instance, examine the geographical, economic and political aspects in such indicators as political alliances, major power, length of river and gross domestic product. Conca's (2006a, b) qualitative analysis examines the nature of treaties, asking how many include aspects of environmental protection, principles of international water law or stakeholder participation. In doing so, he questions the assumption that the existence of a treaty on a basin is evidence of cooperation-an issue we will return to.

Sadoff and Grey move beyond prediction and cataloguing of water conflict to lead the policy-relevant implications of water conflict and cooperation. Starting from the point that 'international rivers in some cases become a powerful catalyst for conflict, or a powerful catalyst for cooperation' (Sadoff and Grey 2002, p. 391), they discuss four main types of cooperative benefits regarding international rivers. ${ }^{2}$ The work has developed the concept of 'benefit-sharing', which appears to have taken some root, at least in the Nile Basin initiative (UNESCO 2004). Sharing of benefits derived from the river (e.g. hydroelectricity), the argument goes, may be more politically feasible and therefore more likely than actual sharing of the transboundary resource itself. Tensions rising from the distributional nature of water conflicts - that is, scrambles for a larger share of the pie-would be reduced, as the pie itself is enlarged. ${ }^{3}$ Gerlak (2007) reviews the global environmental facility's own performance reviews after spending over $\$ 700 \mathrm{M}$ on transboundary water programmes. The results of the seed money designed to encourage cooperation through the "creation of a shared vision' are mixed, with a failure to identify the root causes of the conflict listed as one of the concerns.

The links between water scarcity and conflict have also evolved, with the initial inadequate conceptions of physical scarcity (e.g. Falkenmark and Rockstom 2000), refined by Ohlsson and Turton (1999), Mehta (2001) and Falkenmark et al. (2007) to incorporate

\footnotetext{
2 These include (a) increasing benefits to the river (improved water quality, enhanced biodiversity); (b) increasing benefits from the river (improved management for hydropower or agricultural use); (c) reducing costs because of the river (flood/drought management, reduced international tensions); and (d) increasing benefits beyond the river (benefits deriving from integrated regional markets) (Sadoff and Grey 2002).

3 The concept of benefit-sharing thus offers the possibility of the resolution of water conflicts, and is currently being pursued through negotiations at the Nile Basin Initiative (Mohieldeen 2008), and in research on the Kagera, Mekong and Orange rivers (see, Phillips et al. 2006). The concept has also been proposed as a means of reaching basin-wide agreements amongst all five riparians of the Jordan River, based on the inclusion of desalinated water into the 'pie' (Phillips et al. $2007 \mathrm{a}, \mathrm{b}$ ).
} 
the very relevant social dimensions. Obstacles to collective action over environmental issues (such as physical or constructed water scarcity) are, after all, primarily social, requiring in-depth context-specific understanding (Ostrom 1990). Waterbury (2002), for instance, ably showed nationalism and state interests to preclude collective action between the Nile Basin states.

The theoretical work on the transformation of transboundary water conflict to cooperation has been conducted by the US Army Corps of Engineers, which identifies 17 trends pushing towards cooperation (USACE 1996). Sadoff and Grey (2005) emphasise varying degrees of cooperation, noting that these may be incremental in an evolution from unilateral action $\rightarrow$ coordination $\rightarrow$ collaboration $\rightarrow$ joint action. Similarly, the UNDP 2006 Human Development Report identifies the range of cooperation, from 'coordination (such as sharing information)', 'collaboration (developing adaptable national plans)' and 'joint action (which includes joint ownership of infrastructure assets)' (UNDP 2006, p. 224). Wolf (2008) spots opportunities for improvement through greater 'efficiencies' rendered by focusing on the lag between the start of a conflict and the conclusion of an agreement, and on the rather more violent sub-national contexts. Scheumann and Alker (2008) follow the same approach for addressing the transboundary groundwater issues in Africa. The emphasis on transformation to cooperation is further supported by the work of Green Cross International (e.g. GCI 2000), the Woodrow Wilson ICS Environmental Change and Security Programme's Navigating Peace Initiative (e.g. Conca 2006a, b), and UNESCO's From Potential Conflict to Co-operation Potential programme (e.g. UNESCO 2004).

\subsection{The problems with the 'either/or' approach to conflict and cooperation}

This rich body of work is wholly aware of the very complex set of circumstances under which interaction over transboundary occurs, notably the complexity of time, space and changing political regimes. There is furthermore broad consensus amongst the authors that conflict and cooperation co-exist. The fall-back analytical method, however, is to examine the two as a distinct phenomena. The most common analytical tool that the body of work relies on is the continuum, three variations of which appear in Fig. 1.

The analysis is greatly facilitated when conflict and cooperation are viewed under separate microscopes, and complexities are (at least temporarily) discarded. The use of a continuum forces one to compare the various issues in terms of their relative significance. NATO's continuum (Fig. 1a) sees the relations as 'stages' towards or away from war. While US-Cuban relations are famously poor, for example, the current tolerance of deviation from official rhetoric of both sides would suggest that the neighbours are somewhere between 'unstable peace' and 'crisis' with each other (and yet far from either stable peace or war). Delli-Priscoli (1996, 1998a, b) employs the same device from the perspective of the US Army Corps of Engineers to characterise the differences between consensual ('hot tub') and adversarial ('war') approaches to collaborate for the management of transboundary water disputes (Fig. 1b). In plotting the general relation between two river-basin organisations (RBOs) along the continuum, the author demonstrates, the analyst is obliged to characterise the communication patterns and trust between the parties. At some point (right of point ' $C$ '), relations may be so poor that the parties themselves may not be able to manage their dispute, and external involvement may be required for arbitration.

The most detailed measure of cooperation and conflict directly applied to transboundary water contexts is Yoffe's WEIS (Fig. 1c). The scale ranks the events related to conflict and cooperation at any one of the 15 points. The tool simplifies and enables large- $n$ analysis of 
(a)

Stages of Conflict Development (NATO1999)

DURABLE PEACE

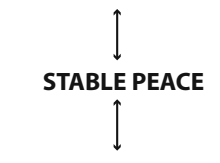

UNSTABLE PEACE

(b)

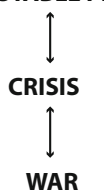

(c)

\section{Water Event Intensity Scale}

(after Yoffe et al. 2003)

7 Voluntary unification into one nation

Major strategic alliance (treaty)

ㅇ 5 Military, economic or strategic support

鹿 4 Non-military ec'c, tech. or ind. agreement

Cultural or scientific support (non-strategic)

Official verbal support of goals, values, or regime

Minor official exchanges or talks...

0 Neutral or non-signific. acts

-1 Mild verbal expressions - discord in interaction

Ł -2 Strong verbal expressions - hostility in interaction

-3 Diplomatic-economic hostile actions

Political-military hostile actions

-5 Small scale military acts

Extensive war acts

Formal declaration of war

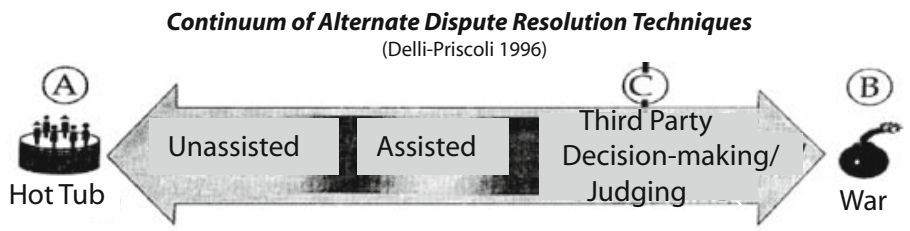

Fig. 1 Three continua of conflict $\leftarrow \rightarrow$ cooperation: (a) NATO's 'stages of conflict development' (1999), (b) Delli-Priscoli's 'continuum of alternative dispute resolution techniques' (1996), and (c) Yoffe et al.'s 'water event intensity scale' (2003)

transboundary water interactive events based on existing databases of river basin physical and administrative characteristics, notably Wolf's Freshwater Transboundary Dispute Database (2004) and the variations of it. The WEIS has proven useful for many of the studies previously discussed, as well as for Wolf et al. (2005), Zeitoun (2007, 2008), and Cascao (2003).

As our brief review of the literature has shown, the use of continua to analyse the interaction between the actors over water issues may narrow our reflections, however, confining our thinking at the risk of over-simplifying complex situations. Continua make it difficult to represent the variations of relations over time and through changed political contexts (as the recent massive political transformations in Iraq have affected relations with Turkey and Syria on the Tigris, for example). Even more importantly, the unidimensional analysis may tend to obscure the multiple political dimensions of interaction. States or trans-national actors may be cooperating in data gathering (' 3 ' on the WEIS), for instance, even while their leaders dispute openly and their armed forces clash ('-4', as in the case of Palestine and Israel (Jägerskog 2003a)). Ethiopian and Egyptian water ministers work to transform the NBI into a commission (nearly '4' on the WEIS), while the tensions arising from the 1959 Sudan-Egypt Treaty ( ' -1 ', retaining the zero allocation of flows to Ethiopia) are in effect excluded from the discussion (Cascao 2008)).

Kistin (2007) noted that this reliance on continua may have unintentionally led to a paradigmatic view that all conflict is 'bad' and that cooperation is inherently 'good'. The tendency has led to policy assuming that relations over transboundary waters may be improved simply by promoting movement along one direction or on one element of the interaction, rather than addressing the broader context as a whole. Considering the many 
less benign faces of cooperation, however, it is not always clear in which direction matters should be pushed.

\section{Faces of transboundary water cooperation}

'Cooperation', it appears, is more complex than we generally tend to think. The purpose of this section is to reveal that cooperation has several 'faces', many of which are not habitually recognised. Lessons from the development, IR and geography literature are drawn upon to explain the difficulties we have with critical evaluation of cooperation, and the political and strategic faces of cooperation are discussed in light of the dominant perception that 'any type of cooperation is good'.

International agreements are generally seen as the pinnacle of cooperation. As Wolf et al. (2003, p. 30) emphasise 'once cooperative water regimes are established through treaties, they turn out to be impressively resilient over time, even when between otherwise hostile riparians, and even as conflict is waged over other issues'. There is certainly evidence to support the observation. However, if important components of the agreement are not implemented, or favour one actor at the expense of a collective win, the result would likely be rated as some form of 'poor' cooperation, or even 'non-cooperation' (Zawahri 2008). Some unimplemented treaties may stand for so long that their words and the evolving (or devolving) reality experienced on the ground are hopelessly distant, such as the Mahakali Treaty between India and Nepal (Gyawali 2001). Fischhendler's (2008) discussion of the deliberate ambiguity built into the water clauses of the 1994 Israel-Jordan Peace Treaty demonstrates that its resilience may ultimately be less important than its failure to confront the distributional issues which drove the parties together in the first instance.

Analysts are thus confronted with the problem of evaluation of the treaties. Daoudy and Kistin (2008) suggest four criteria to measure the effectiveness of treaties (and which may be applicable to broader 'cooperation' in issues other than water): compliance, goals, interests and problem-solving. By looking at the criteria, we can identify cases like the Zambezi and Mekong river basins where, Fox and Sneddon (2007, p. 237) argue, 'agreements are offered and legitimized as a means to advance ecological and human security, [but] they instead often promote state-centric environmental securitisation'. They further assert that 'In both basins genuine environmental security is... being actively undermined by the codification of rules and principles contained in regional agreements. While often cast as environmental agreements, accords over transnational basins-particularly in the Global South-primarily serve as vehicles to promote the development goals (e.g. hydroelectric production and irrigation expansion) of their signatories' (Fox and Sneddon 2007, p. 239).

Kistin (2007, p. 8) calls us to move 'beyond the notion of cooperation as treaties to a more dynamic view of transboundary water cooperation as an on-going and non-linear process in which state and non-state actors establish, challenge, modify and legitimize multi-layered governance structures'. Indeed, the circuitous process challenges the linear logic we employ to maintain deeply-held beliefs - the idea that conflict is inherently 'bad', for example. Tensions may lead to resolution of conflict and thus be considered in a positive light. Wolf's 'unstable cooperation', for example, acknowledges that solutions to tensions over waters may lead to productive confrontation of other political disputes (Zawahri 2008). Jagerskög (2003a) addresses the same nuance when invoking Keohane on the importance of distinguishing between harmony and cooperation, and for understanding that some conflict is necessary for 'real' cooperation. 
However, just as tensions may lead to reduction of conflict, aspects of cooperationsuch as treaties, river basin organisations or regimes-may reinforce it. Young (2003) attributes the role that institutions play in causing environmental problems to issues of fit, interplay and scale, for example. The political context, within which the cooperation occurs, is the key to a final judgement on its merits. Arnstein's (1969) foundational study of asymmetries of power in citizen's participation in cooperative processes provides useful insight into the less considered aspects of cooperation. She provides a scale of levels of participation related to power sharing, as shown in Fig. 2a. These range from 'non-participation' processes, such as being manipulated, to power-sharing structures where control is shared. Token participation, in the form of processes such as 'consultation', 'informing' and 'placating' occupies the large space in between the extremes. Bruns (2003) builds upon Arnstein's ladder and other scales, applying them to water tenure reform. His extended ladder (Fig. 2b) fleshes out the 'power' end of the spectrum, noting the improved results that derive from two-way shared responsibility and cooperation (rung no. 5, for example) compared to one-way communication and imposed decisions (bottom rung).

Arnstein and Bruns' continua differ from Yoffe et al.'s WEIS for acknowledging the nuance of political processes that are active in cooperative events. An inherent weakness of the WEIS is that the definitions leave no space for those cases of established cooperation, where some actors are effectively excluded from treaties, or whose grievances are ignored through relatively low-impact gestures such as minimal data sharing or collection, which may resemble token gestures of cooperation. Brown and Ashman reinforce this view, noting that 'Cooperation must span gaps in culture, power, resources and perspective. ...Effective cooperation requires some degree of mutual influence that allows all the parties to influence and be influenced' (1996, p. 1467, emphasis added).

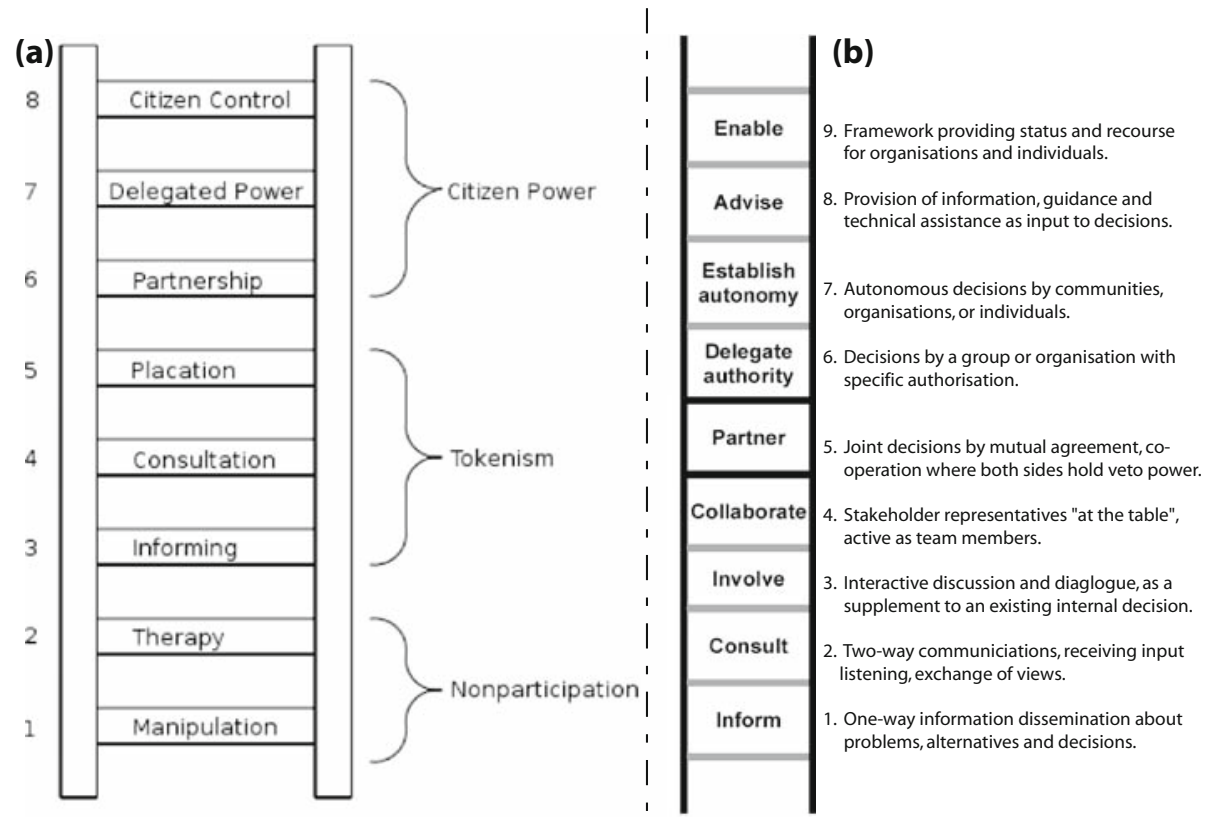

Fig. 2 Two scales of participation: (a) Arnstein's 'ladder of participation' (1969), and (b) Bruns' 'extended ladder of participation' applied to water tenure reform (2003) 
Several disciplines have grappled with the complexity of interpersonal, inter-group or inter-state cooperation. In examining the role of the private sector in environmental governance, for example, Falkner (2003, p. 73) insists that 'it needs to be distinguished from mere cooperation between private actors. Cooperation requires the adjustment of individual behaviour to achieve mutually beneficial objectives'. Brown and Ashman (1996, p. 1473) discuss the problems related to more powerful players framing the issues in transboundary environmental regimes. Cooperation, likewise, may have hidden, strategic aspects—what Daoudy (2007) refers to as 'strategic interaction' and Sosland (2007) as 'tactical functional cooperation'. Barrett (1998) has detailed the strategic behaviour during the pre-negotiations stage of environmental cooperation, noting that actors have their own reasons to stall, hinder, threaten or otherwise obstruct attempts at discussion or negotiation over shared waters.

\subsection{Not all cooperation is pretty}

Analysis of transboundary environmental regimes runs the risk of being off-mark if the complexity of cooperation is not explicitly considered in detail. By focusing on the existence of data-sharing between some Indian and Bangladeshi institutions instead of on the very active political nuances of inter-state relations related to the water conflict on the Ganges River, for example, one might well be convinced that cooperation is occurring. Indeed, on hearing the passionate plea for greater bi-lateral or multi-lateral cooperation over water data and projects made by a Bangladeshi representative at a recent water round-table-to temper the tragic consequences of drought and flood cycles - the Indian representative's response was 'but, we are cooperating' (SIWI 2006). While the veracity of the statement is not in question, the foundational issues that underpin the water conflict (which cannot in any case rationally exclude upstream Nepal) remain ignored. The value of cooperation over the selected issues should be understood within the political context of riparian interactions.

The cases highlighted as examples of cooperation in the 2006 UN World Water Development Report serve to demonstrate the limitations with approaches that do not take into account the political conditions in which it occurs. Table 11.2 of the report highlights the key and recent examples of 'conflicts and cooperation' from South America to Central Asia. Referring to the Friends of the Earth-Middle East's (FOEME) Good Water Neighbours project, which managed to bring together Jordanian, Palestinian and Israeli mayors of Jordan River riparian villages to advocate on the river's behalf, the report states that 'A variety of cooperative programmes have been set up in Jordan, Palestine and Israel to promote the exchange of information and ideas between the different communities in the region. These programmes have also furthered the campaign to protect the Jordan River, which brings stakeholders from the entire region together to work on sustaining the flow of this important river' (UN 2006, p. 380).

The campaign for protection of the Jordan River through unprecedented transboundary cooperation merits the attention given, and one certainly hopes that cooperation would extend to the higher political echelons. The report makes no mention elsewhere, however, of the intractable conflict on the river, which also involves upstream Lebanon and Syria. When taken out of the context, the report's single reference to the Jordan River dispute leaves the reader with the impression that relations between the states over water issues are decent, or at least improving. Conclusions of a similar nature are reached in Feitelson's (2006) liberal analysis of the political economy of the Israeli-Palestinian water conflict, and Sosland's (2007) liberal international relations analysis of Jordan-Israel transboundary water relations. 
These studies make passing, if any, mention of the highly asymmetric 90-10\% distribution of transboundary flows between Israel and Palestine or the (somewhat less asymmetric) distribution between Israel and Jordan. The actual cooperation among Jordanian, Palestinian and Israeli NGOs and mayors could be judged less significant than the more enduring actual conflict at the national level. ${ }^{4}$ Upon studying the Israeli-Palestinian Joint Water Committee's licensing procedure for water projects inside Palestine-which secures an effective veto for Israel if water projects (including basic drinking water projects, such as rainwater cisterns in certain areas) are deemed to threaten state political or military interests-Selby (2003b) insists that this is not cooperation, but 'domination dressed up as cooperation', while Dombrowski (2003, p. 741) considers it as a 'disguise of cooperation'. 5

\subsection{Policy implications}

The collaboration among mayors from three of five sides of the Jordan River-like the minor data-sharing between Bangladesh and India-are actual examples of cooperation in practice. However, as our cursory review has highlighted other less visible aspects, we argue that interaction-whether predominantly conflictual or cooperative (Daoudy 2004) - must be considered in the light of the particular political context in which it occurs. Unquestioned support for any form of cooperation will not allow policy makers to recognise, let alone deal with the shortcomings and detrimental effects of asymmetrical cooperative arrangements (Kistin and Phillips 2007). As Daoudy and Kistin (2008) point out, 'the mere existence of cooperative arrangements is often celebrated as a sign of progress, with little or no interrogation of their influence' over the intended goals of the cooperation. The advice given to lending and implementing agencies in the 2006 UNDP Human Development Report is a case in point:

Cooperation [over transboundary waters] need not always be deep-in the sense of agreeing to share all resources and engaging in all types of cooperative ventures-for states to derive benefits from rivers and lakes. Indeed, given the different strategic, political and economic contexts in international basins, it makes sense to promote and support cooperation of any sort, no matter how slight. (UNDP 2006, p. 228)

With continued support of unquestioned 'cooperation', one might expect to observe the attempts to resolve the conflict, and give way to attempts to manage it, or worse, promote cooperation 'of any sort' as if the risks of reinforcing conflict did not exist. The problems with unquestioned promotion of cooperation 'of any sort' run deep. Under an uncritical mindset the normal indicators of 'cooperation' - such as river basin organisations (RBOs), riparian meetings, annual conferences, joint publications-may be misunderstood as an evidence of the existence of 'cooperation' itself, just as we have discussed with the existence of treaties. The existence of an RBO-like the existence of a treaty-does not mean the existence of 'cooperation'.

There is evidence to suggest that the polarised approach to conflict and cooperation may result in policy where cooperation of any sort becomes itself the goal.

\footnotetext{
4 The national-level conflict has been characterised for over a decade by the Israeli state's refusal to engage in negotiations to quantify the Palestinian water rights that it recognised in the 1995 Oslo II Agreement (Zeitoun 2008).

5 Messerschmid (2007), for his part, asks of the same case whether the political price the cooperation extracts is unreasonable.
} 


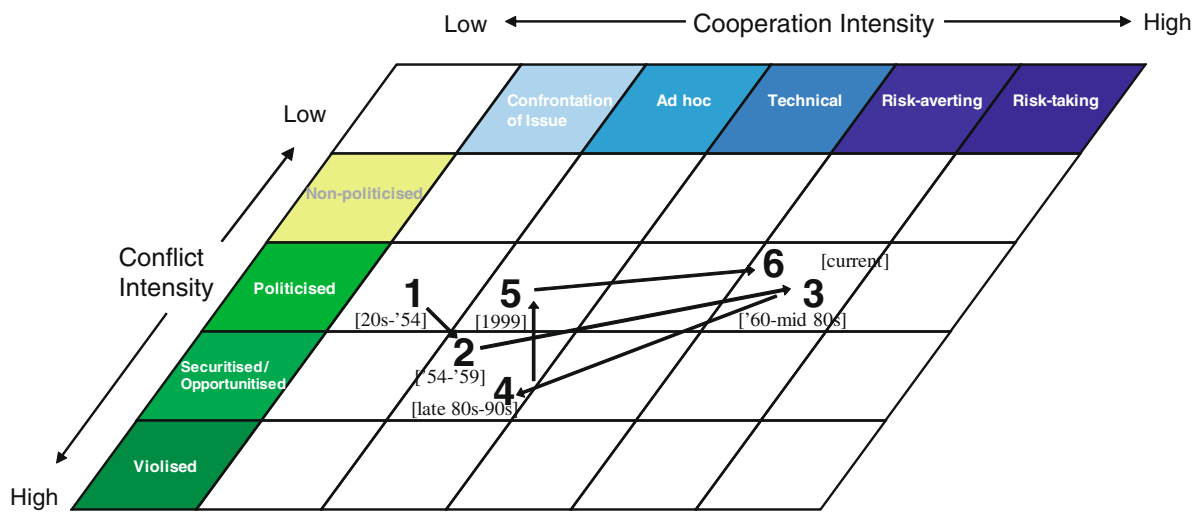

Fig. 3 The TWINS matrix of conflict and cooperation, applied to hydropolitical bilateral relations over time between Sudan and Egypt

Feitelson (2006, p. 320), for example, asks as a main theoretical research question related to the Palestinian-Israeli water conflict, 'what are the impediments to reaching agreements on the management of shared aquifers, and how can these be overcome'? The focus is on how to reach an agreement (the qualities of which are not discussed), and not on the effective management of the aquifers itself. ${ }^{6}$

The fact that there are less visible (or less emphasized) faces of cooperation explains how de-emphasising the root tensions of a conflict may in fact be a step away from its resolution. If we are poorly equipped with an incomplete understanding of 'cooperation', we may be dissuaded from investigating or acting in those important cases, where water conflict also exists. Furthermore, if we plan interventions assuming that cooperation predominates, and ignoring the original cause of conflict, we may in fact perpetuate a wholly inequitable and unsustainable order. An analytical method appreciating the dual nature of transboundary water interaction is required to help us in avoiding such pitfalls.

\section{Transboundary water interaction}

Under the paradigmatic either/or mindset Zeitoun (2007) discussed the so-called 'cooperation versus conflict paradox', seeking to explain the fact that some analysts perceive conflict on a river basin while others see cooperation. There really is no paradox, however. Though researchers are aware that conflictual events and dynamics almost inevitably exist alongside cooperative ones, they are limited in their ability to grapple with and express this fact. Mirumachi's (2007) conception of the Transboundary Waters Interaction Nexus (TWINS) opens the path to deal with the dual nature of interaction. Transboundary water interaction may be understood, examined, analysed and explained by considering positions on a two-dimensional matrix rather than at discrete locations on a spectrum, as in Fig. 3.

The tool is founded on Craig's (1993) argument, which recognised that there are high and low levels of both cooperation and conflict, plotting them on a $2 \times 2$ cell matrix (Mirumachi and Allan 2007). The matrix has been expanded to $5 \times 4$ cells to allow for more detail, and employing labels derived from hydropolitical and security theory for the conflict and cooperation scales, as shown in Fig. 3.

\footnotetext{
${ }^{6}$ In fairness, the same author had worked on precisely this issue in Feitelson and Haddad (2000).
} 
The cooperative $(x)$ scale in the TWINS matrix incorporates the elements of responsibility and power in much the same way that Arnstein's ladder does for participatory processes. Political or strategic intentions to create consensus or goals of joint action increase the intensity of cooperation. The scale ranges from 'confrontation of the issue' at the low extreme to 'risk-taking' interaction at the other extreme. The mid-scale labels of 'ad-hoc', 'technical' and 'risk-averting' enable the analyst to distinguish interactions based on the intent and act. One may plot the difference, for example, between interaction that 'just happens' (i.e. ad-hoc agreement between ferrymen and traders on either side of a boundary-forming river, without external government or outsider interference) and cooperation that has occurred following mutual agreement (i.e. risk-taking projects deriving from the EU Water Framework Directive or global environmental compacts).

The conflictual $(y)$ scale in the TWINS matrix draws upon security theory of the Copenhagen Schools, which Warner (Warner 2004) applied to the interaction over waterrelated issues. According to Fig. 3, an issue or a state of affairs may be perceived within a range from non-politicised ('off the radar', i.e. not an issue, such as minimal river off-takes by small farms) to politicised (the event or state of affairs is an issue, or is being made an issue such that it requires reallocation of national resources and considerations). This may extend to being securitised (the issue is now reframed in existential terms, e.g. state security as in the case of Israel and the 2002 Wazzani Springs dispute with Lebanon (Allouche 2004)) and 'violised' (where the issue has passed beyond the realm of normal politics and into the realm where extreme measures such as warfare, are taken). ${ }^{7}$

The case of relations between the two major riparians on the Nile River serves to briefly exemplify the utility of the tool. Cascao's plot on Fig. 3 of the Egyptian-Sudanese relations onto the TWINS matrix shows the dynamics in these relations, perhaps most remarkably in the period prior to and following the signing of the 1959 Nile Treaty [the path $1 \rightarrow 2 \rightarrow 3 \rightarrow 4$ on Fig. 3]. There has not been a period in recent history, where the Nile flows were non-politicised. Prior to Sudanese independence (point No. 2), Egypt was engaged in undermining the Sudanese government, supporting a coup d'etat. The 1959 treaty was signed favouring Egyptian interests such as the construction of the High Aswan Dam and the Jonglei Canal (in Sudan, to increase the water flow to Egypt), and a distribution of the flows (roughly 75-25\% in Egypt's favour). Sudanese experts generally regard the agreement as unfair, attributing Sudanese acquiescence to it on a pro-Egyptian regime in Khartoum and poorly prepared negotiators.

A generally more cooperative period followed (point No. 3) after signing the treaty, with the Roseries Dam completed within Sudan and the Jonglei Canal project started. The Sudanese civil war upset the stability, and once again changed the nature of the interaction towards more intense conflict. Relations were tense over the 1980s and 1990s, with threats, counter-threats and the destruction of the Jonglei Canal, and were cut off altogether following an attempted assassination of the Egyptian President Mubarak in 1995. Relations were restored in 1999, the same year as the establishment of the Nile Basin Initiative. Egypt was for the first time obliged to engage in multi-lateral relations over the Nile, supporting 'benefit-sharing' projects such as hydropower (path 5 to 6)]. The Egyptian and Sudanese governments since that time have stood united on most water issues (Takele 2004; Eissa 2008), in defiant opposition to the expressed wishes of the upstream riparians. During ongoing negotiations of the new Nile legal framework, Egypt is taking a firm stand against potential re-negotiation of the 1959 treaty so favourable to its position. While the other states remain willing to cooperate through the NBI, tensions over the original

\footnotetext{
7 The theory is substantially elaborated upon and refined in Mirumachi and Warner (2008).
} 
inequality of the treaty remain palpable (Kameri-Mbote 2006), meaning the current plot of relations at point No. 6 may be moving back left or downwards.

The TWINS method allows operationalisation of one of the goals of this paper-that analysts acknowledge, think and work with the dual nature of transboundary water interaction. The selection of scales on both axes of TWINS also allows the political faces of the interaction to emerge, with the explicit recognition that particular faces of cooperation have neutral or less desirable features along with the positive ones. Obliged to plot a position against the opposing axes, the analyst is forced to question the political context which allows differing intensities of conflict and cooperation to co-exist. On viewing the trajectory, one can understand how a 'cooperation' event does not change the status quo of a water regime, or how contained conflict may be sustained. ${ }^{8}$ Consequently, the political context determining different combinations of conflictive and cooperation interactions become a very important analytical focal point.

\section{The political context of water interaction}

This final section intends to demonstrate that transboundary water interaction is besought by the interests, power games, illusions and distrust that accompany all political processes. The various faces of interaction we have thus far seen are captured and linked together-in a first approximation - to the location on the TWINS tool and their potential driving forces.

As a political process, transboundary water interaction may serve strategic purposes, for example to attract external funding, or to share the burden of clean-up costs (Bernauer 2002). Strategy may draw on power asymmetries, of course, particularly if one of the more neutral or less pretty faces of cooperation are in place. Thorough evaluation of transboundary water interaction should thus consider the effects of power asymmetry. As this point is out of the scope of this paper, it suffices to mention here that power asymmetry is usually present, and is sometimes extreme. Along with saliency, power asymmetry serves not only to influence the outcome of a conflict but to affect the actual interactions established. There are reasons explaining, for example, why the clauses of treaties are not enforceable or may be skewed, and the institutions derived from them lie dormant as 'paper tigers' (Bernauer 2002).

If the political context determines the process of interaction, it is worth capturing the political nature of the various faces of cooperation and intensities that we have discussed thus far. These may usefully be categorised into the value-based categories: negative, neutral and positive, as catalogued in Table 1 and described following.

Negative interaction is defined as inter-state interaction inducing a significant degree of resentment with one or more of the actors, thereby negatively affecting the broader political context. Traditional conceptions of conflict as well as the dominative (Selby), coercive and exploitative ugly faces of cooperation that we have seen may (contestably) be considered negative interaction.

Neutral interaction is defined as inter-state transboundary water interaction which may have no inherent effect on the broader political context. Neutral faces of cooper-

\footnotetext{
8 The TWINS plot of Nepalese-Indian relations over the Ganges, for example, supports the view, and demonstrates very little movement in any direction, especially when compared to the plot of the Nile, above (see, Mirumachi 2007).
} 
Table 1 Types and faces of transboundary water interaction (a first approximation)

\begin{tabular}{|c|c|c|c|}
\hline $\begin{array}{c}\text { Characterisation } \\
\text { of Interaction } \\
\text { nexus } \\
\text { (TWINS) }\end{array}$ & Types of Interaction & Examples of Interaction & $\begin{array}{l}\text { Potential Driving } \\
\text { Forces } \\
\text { (non-exhaustive) }\end{array}$ \\
\hline $\begin{array}{l}\text { Low Conflict - } \\
\text { High Cooperation }\end{array}$ & $\begin{array}{l}\text { [positive interaction] } \\
\text { Cooperation on equal terms; } \\
\text { Cooperation across a broad } \\
\text { range of issues; Tensions } \\
\text { reduced through deliberative } \\
\text { processes }\end{array}$ & $\begin{array}{l}\text { Putting in place and exercising } \\
\text { principles (i.e. equitable use, no } \\
\text { harm); } \\
\text { Creation of transboundary } \\
\text { regimes; } \\
\text { Negotiation of a treaty based on } \\
\text { IWL; } \\
\text { Conclusion of an effective treaty } \\
\text { (Kistin) }\end{array}$ & $\begin{array}{l}\text { Benefit sharing / } \\
\text { expanding the pie } \\
\text { Reduction of } \\
\text { environmental } \\
\text { uncertainty }\end{array}$ \\
\hline $\begin{array}{c}\text { Low Conflict - } \\
\text { Med. Cooperation }\end{array}$ & $\begin{array}{l}\quad \text { [neutral interaction] } \\
\text { Narrow cooperation } \\
\text { (cooperation on select issues); } \\
\text { Token cooperation; Mild } \\
\text { verbal expressions of Conflict }\end{array}$ & $\begin{array}{l}\text { Joint pollution management; } \\
\text { Joint infrastructure; } \\
\text { Benefit-sharing based on } \\
\text { agreements; Creation of RBOs }\end{array}$ & $\begin{array}{c}\text { Economic / } \\
\text { Developmental Goals }\end{array}$ \\
\hline $\begin{array}{c}\text { Low Conflict - } \\
\text { Low Cooperation }\end{array}$ & $\begin{array}{l}\quad \text { [neutral interaction] } \\
\text { Minimal or no interaction; Ad- } \\
\text { hoc cooperation; Self- } \\
\text { interested cooperation; Tactical } \\
\text { functional cooperation; } \\
\text { Unstable cooperation }\end{array}$ & $\begin{array}{l}\text { Minor information exchange; } \\
\text { Technical commissions or } \\
\text { meetings; }\end{array}$ & $\begin{array}{l}\text { Improvement of } \\
\text { international } \\
\text { reputation } \\
\text { Sharing of resources }\end{array}$ \\
\hline $\begin{array}{l}\text { Med/High } \\
\text { Conflict - Low } \\
\text { Cooperation }\end{array}$ & $\begin{array}{l}\quad \text { [negative interaction] } \\
\text { Securitised Conflict; } \\
\text { Coercive Cooperation; } \\
\text { Dominative Cooperation; } \\
\text { Violent Conflict }\end{array}$ & $\begin{array}{l}\text { Contained conflict; } \\
\text { Negotiation of treaties not based } \\
\text { on IWL; } \\
\text { Resource capture; } \\
\text { Unilateral environmentalism } \\
\text { (Fischhendler) }\end{array}$ & $\begin{array}{l}\text { Changes in power } \\
\text { symmetry }\end{array}$ \\
\hline
\end{tabular}

Dashed lines indicate fuzzy frontiers - there is overlap between each and every category. IWL = international water law (1997 UN Convention on the Non-navigational Uses of Transboundary Watercourses); RBO = river basin organisation.

ation we have discussed include token, 'non' (Zawahri), narrow (Falkner), tactical functional (Sosland), ad-hoc, self-interested and unstable (Wolf) cooperation. Neutral intensities of conflict correspond with mild verbal expressions', from the Water Event Intensity Scale.

Positive interaction is defined as inter-state interaction that generally tends to meet the interests of the actors, and contributes to improvement or sustained relations at the broader political level. The so-called 'pretty' faces of cooperation that we have seen-i.e. 'effective', or equitable - may (again, contestably) be considered positive interaction. To 'effective' cooperation (Brown), we may add 'broad' cooperation (meaning cooperation across many issues, perhaps not all directly water-related) and 'cooperation on equal terms', whereby the cooperative structures are the result of an inclusionary deliberative process, such as that established along the Jordan River by FOEME.

The examples given are by no means exhaustive; yet we may note some general features. Most faces of cooperation, for example, are subjectively neutral. That is cooperation in and of itself proves neither pure nor manipulative intent, and cannot be rationally divorced from the broader political context. The TWINS nexus assists to posit the interaction within that context, as shown in Table 1 . The table situates transboundary water interaction within the interaction nexus frame, giving examples, and speculating what may drive actors under different circumstances. 
Table 1 reflects the intuitive association of 'positive interaction' with situations of low conflict and high cooperation. The so-called pretty faces of cooperation may result or be driven by the establishment of an effective treaty based on internationally recognised principles, and may be driven by one or all parties' desire to reap benefits 'beyond the basin', to use Sadoff and Grey's expression. It might be argued that the customary watersharing principles codified in international water law are more likely to be practised in situations of low conflict and high cooperation.

The neutral forms of interaction are generally associated with those situations that may be described as minimally cooperative and conflictual, which is the case of the bulk of basins globally. Neutral faces of cooperation might develop under such circumstances when self-interests of the actors align, or where it occurs in an ad-hoc fashion. Such informal cooperation based on coincidentally aligned interests could start off with discussion of principles - and were the broader political context to allow it - that eventually lead to the negotiation of a fair and effective treaty. The conflict transformation approaches of UNESCO, the Woodrow Wilson ECSP and GEF (and Wolf's 'potential efficiencies') are expected to be most successful in such contexts.

As counter-point, we have negative interaction associated with combinations of high conflict and low cooperation. Examples from the Tigris and Jordan rivers in Zeitoun and Warner (2006) show that this may result in or be driven by attempts to capture control of the resources or to contain an asymmetric outcome. This paper has discussed similar outcomes along the Nile and Ganges. The efforts aimed at conflict transformation in these contexts run a higher risk of actually perpetuating the root causes of the conflict, if blind to the political context.

\section{Towards drivers of cooperation}

The relative success of any potential drivers of interaction is inherently dependant on the state of relations between the actors. Dombrowski (2005) applies game theory to consider the effect of mutual benefits as incentives for cooperation, and further investigations into this area are required. Further 'in-basin' drivers might include benefit-sharing, reduction of uncertainty and economic or development goals. Speculatively, these drivers may induce broader cooperation or self-interested and tactical cooperation. 'Out-of-basin' drivers might include negotiations strategies (such as issue-linkage), or changes in power asymmetry, where one side increases its capacity to meet its commitments and responsibilities). Both of these sets of drivers might lead to more 'effective' cooperation, or cooperation on equal terms, and may be encouraged from external forces. Drivers of negative interaction may result from the desire to gain or maintain control of a transboundary water resource, or historical distrust of riparian neighbours. These drivers will be related to power-related features, are less readily influenced by external parties, and elaborated upon in the following paper in the series.

The approximation of Table 1 requires refinement. Perhaps the most interesting feature is that the riparians can choose to emphasise a certain conflictive or cooperation face of interaction, thereby evading attention that may be given to the other face. The implications for the analysts of transboundary water politics are that in retaining our assumptions that any form of cooperation is good, we may miss the hidden stories and determinants of the conflict. The implications for policy-makers are that time, effort and funds may be mis-spent while working on the trappings of cooperation if the broader context of interaction is ignored. 


\section{Conclusion}

This paper has sought to shed new light on the conflict and cooperation in transboundary waters. We have demonstrated how much of the academic community has evolved well beyond the simplistic notion of environmental determinants of the conflict, generally refuting public claims by politicians that water is at the heart of political violence. We have asserted that analysis of transboundary water dynamics should be considered in the broad terms of political interaction rather than in the polarising 'either/or' terms of conflict or cooperation. The uni-dimensional approach, we have argued, may unintentionally mask the nuance that exists in the majority of contexts where conflict and cooperation, in fact, coexist. It also discourages the consideration of the less benign faces of cooperation, leading to unquestioned simplistic mantras such as 'any form of cooperation is good'. We have reinforced the theoretical relevancy of the 'TWINS' approach to analysis of such co-existing conflict and cooperation. The approach permits uncovering of cooperation that may actually be containing conflict, or of low-level conflict that drives resolution at higher levels.

The cooperative side of interaction has been developed to reveal its multiple faces. Here, the effective cooperation based on riparian compliance, goals, interests and problemsolving characteristics has been differentiated from the unchallenged typical indicators of cooperation such as the signing of a treaty or establishment of a river basin initiative. We have seen that 'token' cooperation, on the other hand, may serve to veil or perpetuate conflict. Coercive cooperation may deepen it. The classification of the faces of such transboundary water interaction has been related to the driving forces of interaction, and demonstrated its strategic uses. The drivers may allow an actor perceiving highly cooperative relations to de-emphasize the uglier faces of cooperation. The implications for analysts and policy-makers alike is that neglecting the nuance may lead to incomplete analysis and ineffective policy.

The paper has insufficiently addressed three issues. First, although we noted the influence of power asymmetry in relation to situations of low conflict and low to medium cooperation, we have not examined an adequate evidence base to support it. Similarly, our identification of the strategic features of cooperation has not been substantiated. The third under-developed issue this paper has introduced is that of the drivers of interaction. We have started to compare the types of drivers such as expansion of benefits, which open up political space for interaction, with the rather more closed nature of not willing to relinquish control of the resources. The power-related and strategic features of cooperation, as well as the drivers of interaction, will be developed in detail in the next paper of the series. Given the breadth of the task, they may be the subject of several more.

Acknowledgement This paper derives from the participants and ideas of the Third International Workshop on Hydro-Hegemony: Power, Conflict and Cooperation, held at the London School of Economics and Political Science, May 2007. Special thanks are due to Tony Allan, Ana Cascao, Marwa Daoudy, and Jeroen Warner. Further thanks to Ana Cascao for her assistance in plotting the TWINS matrix, and to three anonymous reviewers.

\section{References}

Allouche, J. (2004). Water nationalism: An explanation of the past and present conflicts in Central Asia, the Middle East and the Indian Subcontinent? $\mathrm{PhD}$ Thesis, Institut universitaire de hautes études internationales, Université de Genève. 
Arnstein, S. R. (1969). A ladder of citizen participation. Journal of the American Institute of Planners, 35(4), 216-224.

Barrett, S. (1998). On the theory and diplomacy of environmental treaty-making. Environmental and Resource Economics, 11(3-4), 317-333.

Bernauer, T. (2002). Explaining success and failure in international river management. Aquatic Science, 64, $1-19$.

Brochmann, M., \& Gleditsch, N. P. (2006). Conflict, cooperation and good governance in international river basins. International Conference-Governance and the Global Water System: Institutions, actors, scales of water governance facing the challenges of global change. Global Water Systems Project, Bonn, Germany, 20-23 June 2006.

Brochmann, M., \& Hensel, P. R. (2008). Peaceful management of international river claims. Paper Prepared for the 49th Annual Conference of the International Studies Association. San Francisco, 26-29 March 2008.

Brown, D. L., \& Ashman, D. (1996). Participation, social capital, and intersectoral problem solving: African and Asian cases. World Development, 9, 1467-1479.

Bruns, B. (2003). Developing an extended ladder of participation. RCSD Conference-Politics of the Commons: Articulating Development and Strengthening Local Practices. Chiang Mai, 11-14 July 2003.

Butts, K. H. (1997). The strategic importance of water. Parameters. US Army War College Quarterly, 27 (Spring 1997), 65-83.

Cascao, A. (2003). Hydropolitics in Ethiopia. Master's Thesis, Lisbon University.

Cascao, A. (2008). Counter-Hegemony in the Nile River Basin. Water Policy, 10(S2), 13-28.

Conca, K. (2006a). The new face of water conflict. No. 3 in the Navigating peace series. Woodrow Wilson International Center for Scholars, Environmental Change and Security Programme, July 2006.

Conca, K. (2006b). The new face of water conflict, No. 3 in the Navigating peace series. Woodrow Wilson International Center for Scholars, Environmental Change and Security Programme, July 2006.

Craig, J. G. (1993). The nature of co-operation. Montreal: Black Rose Books.

Daoudy, M. (2004). Negotiating water in the Middle East: A new analytical framework. Paper Prepared for UNESCO/AUB Symposium on Challenges Facing Water Resources Management in Arid and SemiArid Regions. American University of Beirut, 7-9 October 2004.

Daoudy, M., \& Kistin, E. (2008). Beyond water conflict: Evaluating the effects of international water cooperation. Paper Prepared for the 49th Annual Conference of the International Studies Association. San Francisco, 26-29 March 2008.

de Waal, A. (2007). Darfur and the failure of the responsibility to protect. International Affairs, 83(6), 1039-1054.

Delli-Priscoli, J. (1996). Conflict resolution, collaboration and management in international water resource issues. Alternative dispute resolution series, IWR Working Paper 96-ADR-WP-6. Alexandria, USA: Institute for Water Resources, US Army Corps of Engineers, May 1996.

Delli-Priscoli, J. (1998a). Public involvement; conflict management; and dispute resolution in water resources and environmental decision making. In: J. L. Creightion, C. M. Dunning, J. Delli-Priscoli, \& D. B. Ayres (Eds.), Public involvement and dispute resolution: A reader on the second decade of experience at the institute for water resources. Alexandria, USA: Institute for Water Resources, US Army Corps of Engineers. IWR Report 98-R-5.

Delli-Priscoli, J. (1998b). From hot-tub to war: Alternative dispute resolution (ADR) in the U.S. Corps of Engineers. In: J. L. Creightion, C. M. Dunning, J. Delli-Priscoli, \& D. B. Ayres (Eds.), Public involvement and dispute resolution: A reader on the second decade of experience at the institute for water resources. Alexandria, USA: Institute for Water Resources, US Army Corps of Engineers. IWR Report 98-R-5.

Dombrowski, I. (2003). Water accords in the Middle East peace process: Moving towards cooperation? In: H. G. Brauch, P. H. Liotta, A. Marquina, P. Rogers \& M. el Sayed (Eds.), Security and environment in the Mediterranean-Conceptualising security and environmental conflict. Heidelberg, Germany: Springer. Hexagon Series No. 1.

Dombrowski, I. (2005). Conflict, cooperation, and institutions in international water management. PhD Thesis, Leipzig University.

Eissa, S. (2008). International law and hydro-hegemony in the Nile Basin: A Sudanese perspective. Water Policy, 10 (Supplement 2).

el-Tom, A. O. (2007). UN Ban Ki-Moon and his drought thesis of Darfur conflict. Sudan Tribune 13 (November 2007).

Falkenmark, M., Berntell, A., Jägerskog, A., Lundqvist, J., Matz, M., \& Tropp, H. (2007). On the verge of a new water scarcity: A call for good governance and human ingenuity. Brief, S. P. Stockholm, Stockholm International Water Institute. 
Falkenmark, M., \& Rockstom, J. (2000). Water in emergencies. War and water. Geneva, Switzerland: International Committee of the Red Cross.

Falkner, R. (2003). Private environmental governance and international relations: Exploring the links. Global Environmental Politics, 3(2), 72-87.

Fearon, J. (1995). Rationalist explanations for war. International Organization, 49(3 Summer 1995), 379-414.

Feitelson, E. (2006). Impediments to the management of shared aquifers: A political economy perspective. Hydrogeology Journal, 14, 319-329.

Feitelson, E., \& Haddad, M. (2000). Management of shared groundwater resources: The Israeli-Palestinian case with an international perspective. Ottawa, Canada: International Development Research Council and Kluwer Academic Publishers.

Fischhendler, I. (2008). Ambiguity in transboundary environmental dispute resolution: The Israel-Jordanian water agreement. Journal of Peace Research, 45(1), 91-110.

Fox, C. A., \& Sneddon, C. (2007). Transboundary river basin agreements in the Mekong and Zambezi basins: Enhancing environmental security or securitizing the environment? International Environmental Agreements: Politics Law and Economics, 7, 237-261.

GCI. (2000). National sovereignty and international watercourses. Renens, Switzerland: Green Cross International.

Gerlak, A. K. (2007). Lesson learning and trans-boundary waters: A look at the global environmental facility's international waters program. Water Policy, 9, 55-72.

Gyawali, D. (2001). Rivers, technology and society: Learning the lessons of water management in Nepal. London, UK: Zed Books.

Hartmann, E. (2002). Strategic scarcity: The origins and impact of environmental conflict ideas. PhD Thesis, Development Studies Institute, London School of Economics and Political Science.

Hensel, P. R., \& Brochmann, M. (2007). Armed conflict over international rivers: The onset and militarization of river claims. Annual Meeting of the International Studies Association, March 2007, Chicago.

Homer-Dixon, T. (1995a). Environmental scarcity and violent conflict: The case of Gaza. Project on environment, population and security. Washington, DC, USA: American Association for the Advancement of Science and the University of Toronto, June 1995.

Homer-Dixon, T. (1995b). On the threshold-Environmental changes as causes of acute conflict. In S. M. Lynn-Jones \& S. E. Miller (Eds.), Global dangers: Changing dimensions of international security. Cambridge, USA: MIT Press.

Jägerskog, A. (2003). Why states cooperate over shared water: The water negotiations in the Jordan River basin. Linköping, Sweden: Linköping University.

Kameri-Mbote, P. (2006). Water, conflict, and cooperation: Lessons from the Nile River Basin. No. 4 in the Navigating Peace series, Woodrow Wilson International Center for Scholars, Environmental Change and Security Programme, January 2007.

Ki-Moon, B. (2007). What I saw in Darfur. The Washington Post 14, September 2007, A13.

Kistin, E. (2007). Transboundary cooperation in SADC: From Concept to Implementation. Paper prepared for the 8th WaterNet/WARFSA/GWP-SA Symposium. Lusaka, Zambia, 30 October-3 November 2007.

Levy, M. (2001). A Debate (comments on Levy's Time for a Third Wave of Environment and Security Scholarship). Environmental Change and Security Program Report No.2. Homer-Dixon, T., Porter, G., \& Goldstone, J. (Eds.), Woodrow Wilson International Center for Scholars.

Lewis, L. (2007). Water shortages are likely to be trigger for wars, says UN chief Ban Ki Moon. Times Online. London, World News, 4 December 2007.

Lowi, M. (1993). Water and power-The politics of a scarce resource in the Jordan River Basin. Cambridge, USA: Cambridge University Press.

Mac Ginty, R., Muldoon, O. T., \& Ferguson, N. (2007). No war, no peace: Northern Ireland after the agreement. Political Psychology, 28(1), 1-11.

Mehta, L. (2001). The manufacture of popular perceptions of scarcity: Dams and water-related narratives in Gujara, India. World Development, 29(12), 2025-2041.

Messerschmid, C. (2007). Hydro-hegemony in shared Israeli, Palestinian groundwater resources: What price cooperation? International Conference on Sustainable Development and Management of Water Resources in Palestine. Amman, August 2007.

Middle East Quarterly. (September 1997). Boutros Boutros-Ghali: "I Support the Algerian Government". Middle East Quarterly.

Mirumachi, N. (2007). Fluxing relations in water history: Conceptualizing the range of relations in transboundary river basin. Pasts and Futures of Water: Proceedings from the 5th International Water History Association Conference. Tampere, Finland, 13-17 June 2006. 
Mirumachi, N., \& Allan, J. A. (2007). Revisiting transboundary water governance: Power, conflict cooperation and the political economy. Proceedings from CAIWA International Conference on Adaptive and Integrated Water Management: Coping with Scarcity. Basel, Switzerland, 12-15 November 2007.

Mirumachi, N., \& Warner, J. (2008). Co-existing conflict and cooperation in transboundary waters. Paper prepared for the 49th annual Conference of the International Studies Association. San Francisco, 2629 March 2008.

Moench, M., Dixit, A., Janakarajan, S., Rathore, M. S., \& Mudrakartha, S. (2003). The fluid mosaic-Water governance in the context of variability, uncertainty and change. Ottawa, Canada: International Development Research Centre.

Mohieldeen, Y. (2008). Sudan's Nile waters and the eastern Nile basin: Hydropolitics in a politicized environment. PhD Thesis, Department of Geography, School of Oriental and African Studies.

Najam, A. (2002). International environmental negotiation: A strategy for the south. In L. Susskind, W. Moomaw \& K. Gallagher (Eds.), Transboundary environmental negotiation: New approaches to global cooperation. San Francisco: Jossey-Bass.

Ohlsson, L., \& Turton, A. (1999). The turning of a screw: Social resource scarcity as a bottle-neck in adaption to water scarcity. SOAS Water Issues Study Group, School of Oriental and African Studies/ King's College-London (Occasional Paper 19).

Ostrom, E. (1990). Governing the commons: The evolution of institutions for collective action. Cambridge: Cambridge University Press.

Phillips, D., Attili S., McCaffrey S., \& Murray J. (2007a). The Jordan River Basin: 1. Clarification of the allocations in the Johnston plan. Water International, 31(5), 16-38.

Phillips, D., Attili S., McCaffrey S., \& Murray J. (2007b) The Jordan River Basin: 2. Potential future allocations to the Co-riparians. Water International, 31(5), 39-62.

Phillips, D., Daoudy, M., Öjendal, J., Turton, A., \& McCaffrey, S. (2006). Trans-boundary water cooperation as a tool for conflict prevention and broader benefit-sharing, Global Development Studies No. 4. Stockholm, Sweden: Ministry of Foreign Affairs.

Sadoff, C. W., \& Grey, D. (2002). Beyond the river: The benefits of cooperation on international rivers. Water Policy, 4, 389-403.

Sadoff, C. W., \& Grey, D. (2005). Cooperation on international rivers: A continuum for securing and sharing benefits. Water International, 30(4), 1-8.

Scheumann, W., \& Alker, M. (2008). The way towards joint management of Africa's transboundary aquifers. Groundwater and Climate in Africa, Conference organised by Ministry of Water and Environment of Uganda. University College London, and UNESCO, Kampala, June 24-28, 2008.

Selby, J. (2003). Dressing up domination as 'co-operation': The case of Israeli-Palestinian water relations. Review of International Studies, 29(1), 121-138.

SIWI. (2006). Full-day session on hydro-hegemony. World Water Week August 2006, Stockholm, Sweden.

Sosland, J. K. (2007). Cooperating rivals: The riparian politics of the Jordan River basin. New York, USA: State University of New York Press.

Takele, B. G. (2004). The hydropolitics of transboundary river water resources development: The case of the Blue Nile Basin in Ethiopia. Master's Thesis, Department of Geography, King's College London.

Thomson, M. (2005). Ex-UN chief warns of water wars. BBC News. London, UK, 2 February 2005 [on-line].

UN. (2001). Secretary-General asks United States geographers to work with him to tackle climate change problems, Environmental Degradation and Sustainable Development. UN Press Release SG/SM/7732.

UN. (2006). Water: A shared responsibility. World Water Development Report No. 2. Paris, United Nations Educational, Scientific and Cultural Organisation, World Water Assessment Programme, UN Water.

UNDP. (2006). Beyond scarcity: power, poverty and the global water crisis. Human Development Report 2006. New York, USA: Author.

UNESCO. (2004). From potential conflict to co-operation potential: Promoting water as a catalyst for peace through capacity building, research and technical assistance. Paris, France, A contribution of UNESCO's International Hydrological Programme to the World Water Assessment Programme—2nd Phase.

USACE. (1996). Conflict resolution, collaboration and management in international water resource issues. Alternative Dispute Resolution Series, Working Paper \#6. Alexandria, USA: Author.

Vasquez, J. A., Johnson, J. T., Jaffe, S., \& Stamato, L. (1995). Learning conflict resolution in the Post-Cold War Era. Michigan, USA: University of Michigan Press.

Warner, J. (2004). Water, wine, vinegar and blood. On politics, participation, violence and conflict over the hydrosocial contract. Proceedings from Water and Politics Conference (26-27 February 2004, Chap. 3). Marseilles, France, 15 March 2004.

Waterbury, J. (2002). The Nile: National determinants of collective action. Ann Arbor, MI, USA: Yale University Press. 
Wolf, A. (2008). Healing the enlightenment rift: Rationality, spirituality, and shared waters. International Affairs, 61(2).

Wolf, A. T. (2004). Freshwater transboundary dispute database. Corvallis, OR, USA: Oregon State University.

Wolf, A. T. (2007). Shared waters: Conflict and cooperation. Annual Review of Environmental Resources, 32, 241-269.

Wolf, A. T., Kramer, A., Carius, A., \& Dabelko, G. D. (2005). Managing water conflict and cooperation. State of the World 2005: Redefining Global Security, Worldwatch Institute.

Wolf, A. T., Yoffe, S., \& Giordano, M. (2003). International waters: Identifying basins at risk. Water Policy, 5(1), 29-60.

Young, O. (2003). Environmental governance: The role of institutions in causing and confronting environmental problems. International Environmental Agreements: Politics Law and Economics, 3(4), 377-393.

Zawahri, N. (2008). Capturing the nature of cooperation, unstable cooperation, and conflict over international rivers: The story of the Indus, Yarmouk, Euphrates, and Tigris rivers. International Journal of Global Environmental Issues, 8(3), 286-310.

Zeitoun, M. (2007). The conflict vs. cooperation paradox: Fighting over or sharing of Palestinian-Israeli groundwater? Water International, 32(1), 105-120.

Zeitoun, M. (2008). Power and water: The hidden politics of the Palestinian-Israeli conflict. London: I. B. Tauris.

Zeitoun, M., \& Warner, J. (2006). Hydro-hegemony: A framework for analysis of transboundary water conflicts. Water policy, 8, 435-460. 